\section{AgNPs: The New Allies Against $S$. Mutans Biofilm - A Pilot Clinical Trial and Microbiological Assay}

\author{
Priscila L.L. Freire ${ }^{1}$, Allan J.R. Albuquerque ${ }^{2}$, Fabio C. Sampaio ${ }^{2}$, André
} Galembeck $^{3}$, Miguel A. P. Flores ${ }^{3}$, Thayza C. M. Stamford ${ }^{3}$, Aronita Rosenblatt ${ }^{1}$
${ }^{1}$ FOP - Faculdade de Odontologia de Pernambuco, UPE - Universidade de Pernambuco, Recife, PE, Brazil ${ }^{2}$ UFPB - Universidade Federal da Paraíba, João Pessoa, PB, Brazil ${ }^{3}$ UFPE - Universidade Federal de Pernambuco, Recife, PE, Brazil

Correspondence: Priscila L.L. Freire, Avenida Gal. Newton Cavalcanti, 1650, 54753-020 Camaragibe, PE, Brasil. Tel: +55-83-3252-1053. e-mail: priscilallf@gmail.com

\begin{abstract}
The purpose of this study was to evaluate the antimicrobial properties of a new formulation containing silver nanoparticles, named Nano Silver Fluoride (NSF), to inhibit Streptococcus mutans biofilm formation on children's dental enamel. The variations in dental biofilm $\mathrm{pH}$ and in the Simplified-Oral-Hygiene-Index (OHI-S) also were evaluated after the treatment with NSF. This was a randomized, double-blind, crossover and prospective pilot clinical trial study in which 12 schoolchildren, aged between 7-8 years, had their dental enamel treated with two solutions: S1 - Nano Silver Fluoride and S2 - negative control (saline solution), in different experimental moments. The dental biofilm adhered to enamel treated with NSF had lower values of S. mutans viability (absorbance) and colony forming units (CFU) than the SO (baseline) and S2. There was a statistically significant difference between the OHI-S mean values of S0 and S1. There were no differences between the biofilm pH (both before and after the use of the test substances) and among the different groups. These properties suggest that NSF has bactericidal effect against $S$. mutans biofilm and it may be used for clinical control and prevention of dental biofilm formation.
\end{abstract}

Key Words: silver nanoparticles, antimicrobial activity, biofilm, cariostatic agents, S. mutans.

\section{Introduction}

Dental caries remain a major public health issue that affects $95 \%$ of the world's population, mostly in developing countries, which lack access to dental care (1). Owing to its acidogenic and aciduric characteristics that contribute to colonization of the tooth surface, dental plaque formation and to demineralization of hard dental tissues, Streptococcus mutans is regarded as the main bacterium related to the initiation of dental caries (2).

A new experimental formulation containing silver nanoparticles, chitosan and fluoride, called Nano Silver Fluoride (NSF), which arrests and prevents caries in children, claims to have ideal chemical, physical and antibacterial properties. Silver nanoparticles (AgNPs) interact with organic and inorganic molecules depending on both their size and shape, since the nanoparticles have a large surface area that allows broad interactions (3).

In dentistry, 38\% Silver Diamine Fluoride (SDF), $\mathrm{Ag}\left(\mathrm{NH}_{3}\right)_{2} \mathrm{~F}$, has been used to arrest caries since 1969 (4). Laboratory studies have reported that SDF prevents the formation of Streptococcus mutans, Streptococcus sobrinus, Actinomyces naeslundii, Lactobacillus acidophilus and Lactobacillus rhamnosus biofilms (5), but its use for dental purposes is generally not encouraged, because it induces black tooth discoloration. However, the use of nanoscale has eliminated this problem, either in caries lesion or in healthy dental tissue, in addition to enhancing chemical and antimicrobial properties and reducing cell toxicity (6-11). AgNPs also have little or no cytotoxicity $(6,7)$ and clinical application has become possible without risks.

The bactericidal activity and stability of silver nanoparticles are believed to be influenced by the nature of the stabilizing agent used in the formulation, which must allow constant interaction between the silver nanoparticles and bacteria (11-15). Bactericidal effects have also been observed for cells organized in biofilms, due to nanoparticle interference in "cell to cell" aggregation and "cell-surface" adherence $(6,15)$. It has also been reported that the silver particles may inhibit free glycosyltransferases, the enzymes responsible for promoting glucose and cell adhesion that enables the production of glycans and extracellular polysaccharides. The described mechanism may disturb cell respiration and change cell metabolism (13).

The properties of this novel product suggest its potential as an effective cariogenic biofilm inhibitor, with both aesthetic and antimicrobial advantages over traditional silver fluoride products. These characteristics 
suggest clinical trials for AgNPs products to prove their in vivo antimicrobial action against S. mutans biofilm. This study evaluated the antimicrobial efficacy of Nano Silver Fluoride on S. mutans growth in children's dental biofilms, variations in dental biofilm $\mathrm{pH}$ after product application and the Simplified-Oral-Hygiene-Index $(\mathrm{OHI}-\mathrm{S})$ of the treated tooth surfaces.

\section{Materials and Methods}

\section{Ethical Aspects}

The study was approved by the Research Ethics Committee of Universidade de Pernambuco University (UPE), protocol (CEP-in 265-619). The project was registered at Clinical Trials.gov under protocol NCT01950546. All caregivers for the children signed a free and informed consent form to allow their participation in study.

\section{Nano Silver Fluoride Formulation}

The experimental NSF solution was synthesized according to Targino et al. (7). The silver nanoparticles were characterized by UV-Visible (UV-vis) in a DH-2000 Mikropack Transmission Electron Microscopy (TEM) on a FEI-Tecnai20 at an accelerating voltage of $200 \mathrm{kV}$. Tem analysis revealed that $97 \%$ of the silver nanoparticles were spherical and particle size was $8.7 \pm 3.1 \mathrm{~nm}$.

\section{Clinical Assay}

\section{Sample}

The sample was comprised of 12 schoolchildren of both genders, aged between 7 and 8 years and regularly enrolled in the Municipal School Anita Trigueiro do Valle in João Pessoa, PB, Brazil.

\section{Inclusion Criteria}

The volunteers should be children whose parents had signed the informed consent form for their participation in the study and who were not using antimicrobial substances such as mouthwashes and antibiotics or immunosuppressing drugs for at least one month before the study began. The volunteers were required to have the following index teeth: permanent maxillary right central incisor (8), permanent mandibular left central incisor (24), permanent maxillary and mandibular first molars $(3,14,19)$; to attend classes during the week of collection; not having systemic health involvement; who did not use braces and without carious lesions (white spot or cavitated), supra-gingival calculus, gingivitis or malocclusions in the index teeth.

The study was randomized, double blind, crossover and prospective. The children's dental enamel was treated with two solutions - Nano Silver Fluoride (S1) and negative control (saline solution - S2) at different experimental moments. Neither the researcher nor the participants were aware of the treatment delivered at each experimental period. Each subject received both treatments. Microsoft Excel $2003^{\circledR}$ software was used to randomly allocate the selected group volunteers in two groups, according to the two solutions: S1 and S2. Codes were assigned by a biostatistician and decoded only at the end of the study.

\section{Sample Standardization}

All the volunteers received a hygiene kit containing soft toothbrush (Condor Trip ${ }^{\circledR}$, Condor, São Bento do Sul, SC, Brazil), tooth paste without fluoride (Cocoricó,TuttiFruti, Sem Flúor, Bitufo Hypermarcas ${ }^{\circledR}$, São Paulo, SP, Brazil) and oral hygiene guidelines. At the beginning of the study, all participants received a professional prophylaxis to remove plaque and to standardize the oral cavity with the lowest possible amount of biofilm. To complete the standardization, each volunteer used the dentifrice kit for 7 days (cleaning or "wash-out" time), from before the study beginning until the end of the study. The volunteers were told not to use any product containing antimicrobial substances (mouthwash, toothpaste, gel) during the experiment days, but just to brush their teeth 3 times a day with the kit provided by the researcher.

\section{Applications of the Solutions}

The study was randomized, double blind, crossover and prospective. The subjects used two solutions and neither the researcher nor the participants were aware of which treatment was delivered. Microsoft Excel $2003^{\circledR}$ software was used to randomly allocate the selected group volunteers into two distinct groups: S1- nanosilver fluoride, and S2 - negative control (saline solution). There were two experimental times of solution application., in one there were children treated with S1 and children treated with S2. In the second experimental time, after one week without solution application (wash out period) the volunteers were treated with a different solution from the one they were treated in the first experimental time. All volunteers used both solutions. Codes were kept for assignment by a biostatistician and decoded only at the end of the study. Five-milliliter portions of S1 and S2 solutions were applied using a disposable microbrush (KG Sorensen ${ }^{\circledR}$, Cotia, SP, Brazil), on the buccal surfaces of permanent maxillary right central incisor (8), permanent maxillary first molars $(3,14)$, permanent mandibular left central incisor (24) and lingual surfaces of the permanent mandibular first molars (19). 


\section{Biofilm $\mathrm{pH}$}

The measurements of dental biofilm $\mathrm{pH}$ were performed with a Beetrode (WPI Inc., Sarasota, FL, USA) microelectrode connected to a potentiometer (Orion $230 \mathrm{~A}$ ). Its calibration was maintained between 4 and $7 \mathrm{pH}$. The standard measurement times were: "baseline" (T0 - before product application), T1 (30 min after product application), and T24 (24 h after product application). Only the buccal surfaces of the permanent maxillary molars ( 3 and 14 ) were measured to assess whether the products caused some change in the biofilm $\mathrm{pH}$ in the experimental period.

\section{OHI-S Index}

A single examiner examined all subjects. The examinations were performed in a classroom with adequate artificial illumination, using latex gloves and dental mouth mirrors. The Simplified Oral Hygiene Index (OHI-S) was used to analyze the clinical biofilm parameters (16). It assessed the amount of visible biofilm with a plaque disclosing agent on the surface of index teeth: the buccal surfaces of permanent maxillary right central incisor (8), permanent mandibular left central incisor (24), permanent maxillary first molars $(3,14)$ and lingual surfaces of the permanent mandibular first molars $(19,30)$. The $\mathrm{OHI}-\mathrm{S}$ was measured at the following study times: T0 (baseline) and T24 hours, always after $\mathrm{pH}$ measurement and before biofilm collection.

Each tooth was scored according to the condition found: $0=$ absence of colored biofilm; $1=$ colored biofilm surface corresponding to $1 / 3$ of the tooth surface; $2=$ colored biofilm surface corresponding to $2 / 3$ of the tooth surface; $3=$ colored biofilm corresponding to the complete tooth surface.

\section{Biofilm Collection}

The dental biofilm was fully collected after staining with a sterile dental curette and transferred to a tube containing $1.0 \mathrm{~mL}$ of sterile phosphate-buffered saline (PBS) at T0 (baseline) and T24. The tubes containing

the biofilm were refrigerated (a portable cooler with ice) and immediately sent to the laboratory.

\section{Laboratory Phase}

This phase was performed in the Oral Biology Laboratory (Universidade Federal da Paraiba). The tubes were submitted to sonication in an ultrasonic apparatus (UltrasonicCleaner ${ }^{\circledR}$, Odontobrás, Ribeirão Preto, SP, Brazil) for $2 \mathrm{~min}$ to release the adhered bacteria. Next, they were centrifuged in a micro-centrifuge for 10 min to precipitate the dispersed biofilm. The bacterial growth was then measured by spectrophotometry using OD. The use of OD technique for monitoring growth kinetics is widely used because of its speed and simplicity (17). The supernatant was discarded from the tubes and the biofilm was re-suspended in $1 \mathrm{~mL}$ of sterile phosphate-buffered saline. Then the tubes were vortexed and $100 \mu \mathrm{L}$ were transferred to a microplate, where the absorbance values were measured. Then, the suspensions were serially diluted $\left(10^{-1}, 10^{-2}, 10^{-3}\right)$ and $20 \mu \mathrm{L}$ of each dilution were seeded in Petri plates containing MSKB medium (in triplicate), a modification of Mitis salivarius medium supplemented with 15\% sucrose and a $1 \%$ solution of potassium tellurite. To this medium were added $500 \mu \mathrm{g} / \mathrm{mL}$ of kanamycin and $50 \mathrm{IU} / \mathrm{mL}$ of bacitracin. MSKB is specific for isolation of S. mutans (18). The plates were incubated at $37^{\circ} \mathrm{C}$ for $48 \mathrm{~h}$, under microaerophilic conditions (jar with candle system). A single trained investigator performed the counting of colony forming units (CFU) using a counter (Phoenix CP608 ${ }^{\circledR}$, Phoenix Luferco, Araraquara, SP, Brazil). The means of the triplicate counts (multiplied by the dilution factor) resulted in the final bacterial count (expressed in colony forming units - CFU/mg). The calibration performed for this step showed an excellent intra-examiner agreement $($ Kappa $=0.91)$ was achieved.

\section{Statistical Analysis}

Microsoft Excel $2010^{\circledR}$ software was used for statistical analysis of the data. The CFU count, the supernatant and biofilm absorbance, the biofilm $\mathrm{pH}$ and the OHI-S index data for the different

Table 1 . The averages of $S$. mutans colony forming units (CFU) counting, $S$. mutans viability values in dental biofilm( absorbance) and the OHI-S averages values that were measured in the standard times: baseline and $24 \mathrm{~h}$ after the solutions applications on dental biofilm

\begin{tabular}{lccc}
\hline Group & $\begin{array}{c}\text { CFU/mg } \\
(\mathrm{mean} / \mathrm{SD})\end{array}$ & $\begin{array}{c}\text { S. mutans viability } \\
\text { (absorbance) }\end{array}$ & $\begin{array}{c}\text { OHI-S values } \\
\text { Mean/SD }\end{array}$ \\
\hline Baseline & $34 \times 10^{4} \pm 4.3 \times 10^{4}$ & 0.237 & $1.75 \pm 0.32$ \\
S1 & $8.6 \times 10^{4} \pm 2.7 \times 10^{4}$ & 0.130 & $1.35 \pm 0.13$ \\
S2 & $26.7 \times 10^{4} \pm 3.6 \times 10^{4}$ & 0.239 & $1.72 \pm 0.11$ \\
& ANOVA $(\mathrm{p} \leq 0.05)$ & ANOVA $(\mathrm{p} \leq 0.05)$ & ANOVA $(\mathrm{p} \leq 0.05)$ \\
\hline
\end{tabular}
groups, NSF and negative control were analyzed by ANOVA test for repeated measures, because the data were normally distributed. The T-test was carried out to analyze the difference between variations in S1, S2 and the baseline group values. A Pearson's correlation coefficient was performed to analyze the relationships between the CFU count and the $\mathrm{OHI}-\mathrm{S}$ values. The 
significance level for all tests was $5 \%(p \leq 0.05)$.

\section{Results}

When the CFU counts between the groups and different dilutions were compared, there were statistically significant differences among the baseline, $S 1$ and S2 groups ( $p=0.004)$. The samples treated with NSF revealed lower CFU counts compared to the other groups (Table 1). There was a statistically significant difference of the CFU counts of the groups ( $p=0.0097)$, with statistically significant differences $(p=0.004)$ between the values at baseline and S1 (Table 1). The dental biofilm absorbance after $24 \mathrm{~h}$ of solution application revealed that values for S1 were lower than those found for S2 ( $p=0.0007)$. There was a real reduction in the $S$. mutans growth in enamel treated with the NSF (Table 1). When the biofilm $\mathrm{pH}$ values were compared (at different times, as well as between different groups), there was no statistically significant difference between them ( $p=0.27)$ (Table 2). There was a statistically significant difference between the $\mathrm{OHI}-\mathrm{S}$ mean values at baseline and S1 ( $p=0.02)$ (Table 1). The Pearson's correlation showed no correlation between $\vec{s}$ the CFU counts and OHI-S values $(r=-0.13)$.

\section{Discussion} that each one will yield its own results to answer the research questions and it may anticipate results. This test evaluated the feasibility and usefulness of the collection methods in each execution phase, in order to review and improve the necessary points. Finally, the pilot study is a valuable instrument, since it allows the researcher to reach the context of his research more experienced and with more refined methodological choices. For these reasons, the present study did not show experimental limitations.

The CFU count showed that AgNP product reduced S. mutans growth compared with the baseline and the negative control group. The same bactericidal effect was observed by absorbance of the collected biofilm, in

Table 2. Biofilm $\mathrm{pH}$ mean values at different study times

\begin{tabular}{lc}
\hline Group & $\mathrm{pH}$ values (Mean \pm SD) \\
\hline pH T0 & $6.22 \pm 0.06$ \\
pH T1 S1 & $6.39 \pm 013$ \\
pH T24 S1 & $6.15 \pm 0.17$ \\
ph T1 S2 & $6.26 \pm 0.04$ \\
pH T2 S2 & $6.09 \pm 0.16$ \\
\hline
\end{tabular}

ANOVA $\mathrm{p} \leq 0.05$. which the S1 values were lower than in the other groups. These results agree with those reported in previous studies $(7,13-15,19)$ performed in a static biofilm model, which verified greater $S$. mutans adherence inhibition zones (non-stained zones) and antimicrobial effects on dental enamel surfaces treated with spherical AgNPs. Similar results were found by Freire et al. (6) in a dynamic biofilm model, where four AgNP colloids presented better bactericidal effects against $S$. mutans than those produced by $30 \%$ SDF. The antimicrobial activity of silver nanoparticles is influenced by the size: the smaller the particles, the greater antimicrobial effect. This suggests the possibility that the AgNPs may also penetrate inside the bacteria. Nanoparticles sizes from 1 to 10 $\mathrm{nm}$ attach to the cell surface and drastically disturb membrane permeability and respiration functions. The nanoparticles are also able to penetrate the bacteria and cause further damage, possibly by interacting with sulfur-and phosphorus-containing compounds such as DNA $(3,20,21)$. Targino et al. (7) verified that the MIC value of NSF was lower than the ones found to 30\% SDF over S. mutans biofilm, which indicated that the new product could replace the traditional silver compound as a bactericide and bacteriostatic agent. In the same way, the NSF formulation was effective to arrest active dentin caries in children after one year of application and did not stain teeth (8). These results suggest NSF as a promising product for controlling the cariogenic process and to avoid cariogenic biofilm formation on tooth surface. Silver nanoparticle products involve very low metal concentrations, which are enough to inhibit the development of S. mutans strains. Due to the low silver concentrations, no color changes were observed on the teeth treated with NSF $(6,8)$. Zhang et al. (22) suggest the use of silver nanoparticles in adhesives, composites, cements and sealants to inhibit biofilms and caries.

Biofilms consist in agglomerates of food debris and bacteria, not only microorganisms. To analyze the clinical biofilm parameter was used the Simplified Oral Hygiene Index OHI-S (16), which assessed the amount of visible biofilm by a plaque disclosing agent on the surface of the teeth. The study revealed a decrease in $\mathrm{OHI}-\mathrm{S}$ values for the $\mathrm{S} 1$ group. There was also no relationship between the $\mathrm{OHI}-\mathrm{S}$ values and CFU count. Thus the index does not provide the visible biofilm composition and is much more related to dental hygiene and dietary habits than to the amount of live bacteria.

In the present study there were no differences between the values of biofilm $\mathrm{pH}$ (both before and after the use of the test substances) and between the different groups. The presence of $\mathrm{NaF}$ and $\mathrm{Ag}$ in the 
NSF did not change biofilm $\mathrm{pH}$. These results disagree with those found by Bradshaw et al. (23), where fluoride inhibited critical metabolic processes (direct effect) and also reduced environmental acidification (indirect effect) in biofilms. This is justifiable as the degree and rate of $\mathrm{pH}$ decline increases with carbohydrate concentration in the food, particularly refined sugars, so that plaque $\mathrm{pH}$ can reach values less than 5.0 and remain low for some time (24). In the present study, there was no control over the children's carbohydrate ingestion. There was no significant decrease in biofilm $\mathrm{pH}$ in $\mathrm{S} 1$ and this may be explained by decreases in the number of $S$. mutans. This was evidenced by the CFU counts and the absorbance analyses, because this species degrades carbohydrates rapidly, with formation of large amounts of acid that reduce the biofilm $\mathrm{pH}$ (25).

Nanosilver fluoride was an effective dental biofilm inhibitor because it reduced the S. mutans CFU counts and absorbance values. The product had no effect over biofilm $\mathrm{pH}$ and it reduced IHO-S values. More studies are required to understand the NSF action mechanism in dental biofilm and in dental structure.

\section{Resumo}

0 objetivo do presente estudo foi avaliar as propriedades antimicrobianas de uma nova formulação composta por nanopartículas de prata, denominada nano silver fluoride (NSF), na inibição de biofilme de Streptococcus mutans sobre a superfície do esmalte dentário de crianças. Variações no $\mathrm{pH}$ do biofilme dental e nos valores do índice de Higiene Oral Simplificada (IHO-S) também foram avaliadas após o tratamento com NSF. Trata-se de um estudo piloto, randomizado, duplo cego, cruzado e prospectivo. A amostra foi composta por 12 crianças, de ambos os gêneros, com idades entre 7 e 8 anos, as quais utilizaram as duas soluções testes, S1- NSF e S2- controle negativo (solução salina). 0 biofilme dental tratado com NSF apresentou menores valores de viabilidade de $S$. mutans (absorbância) e de unidades formadoras de colônias (UFC) do que o biofilme baseline e o biofilme tratado com S2. Houve diferença estatisticamente significativa entre os valores médios de IHO-S dos grupos baseline e S1, com uma redução dos valores. Não houve qualquer variação nos valores de $\mathrm{pH}$ do biofilme dental, antes e depois do tratamento com S1 e S2 e entre os diferentes grupos. Estas propriedades sugerem que NSF possui efeito bactericida sobre o biofilme de $S$. mutans, podendo ser utilizado clinicamente para o controle e prevenção da formação do biofilme dentário.

\section{Acknowledgements}

The authors wish to thank the Brazilian Ministry of Education (CAPES) and the Brazilian Ministry of Science and Technology (CNPq). The authors have no conflict of interests with other people or organizations.

\section{References}

1. Loyola-Rodriguez JP, Martinez-Martinez RE, Flores-Ferreyra BI, Patiño-Marin N, Alpuche-Solis AG, Reyes-Macias JF. Distribution of Streptococcus mutans and Streptococcus sobrinus in saliva of Mexican preschool caries-free and caries-active children by microbial and molecular (PCR) assays. J Clin Pediatr Dent
2008;32:121-126

2. Parisotto $T M$, King WF, Duque $C$, Mattos-Graner RO, SteinerOliveira C, Nobre Dos-Santos $\mathrm{M}$, et al.. Immunological and microbiologic changes during caries development in young children. Caries Res 2011;45:377-385.

3. Rai M, Yadav A, Gade A. Silver nanoparticles as a new generation of antimicrobials. Biotechnol Adv 2009;271:76-83.

4. Nishino M, Yoshida S. Clinical effects of diamine silver fluoride on caries and on pulp of deciduous teeth. Jpn J Pedodont 1969;7:5559.

5. Mei ML, Li QL, Chu CH, Lo EC, Samaranayake LP. Antibacterial effects of silver diamine fluoride on multi-species cariogenic biofilm on caries. Ann Clin Microbiol Antimicrob 2013 26;12:4. doi: 10.1186/1476-0711-12-4.

6. Freire PLL, Stamford TCM, Albuquerque AJR, Sampaio FC, Cavalcante HMM, Macedo RO, et al.. Action of silver nanoparticles towards biological systems: cytotoxicity evaluation using hen's egg test and inhibition of Streptococcus mutans biofilm formation. Int J Antimicrob Ag 2015;45:183-187.

7. Targino $A G R$, Pelagio-Flores $M A$, Santos $V E$, Bezerra FGB, Pessoa $H L F$, Gallembeck $A$, et al.. An innovative approach to treating dental decay in children. A new anti-caries agent. J Mater Sci Mater Med 2014;25: 2041-2047.

8. Dos Santos VE, Vasconcelos Filho A, Targino AGR, Pelagio Flores MA, Galembeck A, Caldas AF, Rosenblatt A. A new silver bullet to treat caries in children - Nano Silver Fluoride: A randomised clinical trial. J Dent 2014;42:945-951.

9. Holister P, Weener JW, Romas Vas C, Harper T. Nanoparticles: Technology White Papers 3. Cientific Ltd. 2003;2-11.

10. Hernández-Sierra JF, Ruiz $F$, Cruz Pena DC, Martínez-Gutiérrez $F$, Martínez $A E$, de J. Guillén $A$, et al.. The antimicrobial sensitivity of Streptococcus mutans to nanoparticles of silver, zinc oxide and gold. Nanomedicine 2008;4:237-240.

11. Martinez-Gutierrez F, Thi EP, Silverman J, de Oliveira CC, Svensson SL, Hoek AV, et al.. Antibacterial activity, inflammatory response, coagulation and cytotoxicity effects of silver nanoparticles. Nanomedicine 2012;8:328-336.

12. Liu JL, Luo Z, Bashir S. A progressive approach on inactivation of bacteria using silver-titania nanoparticle. Biomater Sci 2013;1:194-201.

13. Espinosa-Cristóbal LF, Martínez-Castañón GA, Loyola-Rodríguez JP, PatiñoMarín N, Reyes-Macías JF, Ruiz F. Antimicrobial sensibility of Streptococcus mutans serotypes to silver nanoparticles. Mater Sci Eng C 2012;32:896-901.

14. Espinosa-Cristóbal LF, Martínez-Castañón GA, Martinez-Martinez RE, Loyola-Rodrígues JP, Patiño-Marín N, Reyes-Macías JF, et al.. Antibacterial effect of silver nanoparticles against Streptococcus mutans. Mater Lett 2009;63:2603-2606.

15. Espinosa-Cristóbal LF, Martínez-Castañón GA, Téllez-Déctor EJ, Niño-Martínez N, Zavala-Alonso NV, Loyola-Rodríguez JP. Adherence inhibition of Streptococcus mutans on dental enamel surface using silver nanoparticles. Mater Sci Eng C Mater Biol Appl 2013;33:2197-2202.

16. Greene JC, Vermillion JR. The simplified oral hygiene index. J Am Dent Assoc 1964;68:7-13.

17. Myers JA, Curtis BS, Curtis WR. Improving accuracy of cell and chromophore concentration measurements using optical density. BMC Biophys 2013;6:2-15.

18. Kimmel L, Tinanoff N. A modified Mitis salivarius medium for a caries diagnostic test. Oral Microbiol Immunol 1991;6:275-279.

19. Chatterjee T, Chatterjee BK, Majumdar D, Chakrabarti P. Antibacterial effect of silver nanoparticles and the modeling of bacterial growth kinetics using a modified Gompertz model. Biochim Biophys Acta 2015;1850:299-306.

20. Morones JR, Elechiguerra $J \mathrm{~L}$, Camacho $\mathrm{A}$, Holt $\mathrm{K}$, Kouri JB, Ramirez JT, et al.. The bactericidal effect of silver nanoparticles. Nanotechnology 2005;16:2346-2353.

21. Baker C, Pradhan A, Pakstis L, Pochan DJ, Shah SI. Synthesis and antibacterial properties of silver nanoparticles. J Nanosci 
Nanotechnol 2005;2:244-249.

22. Zhang K, Cheng L, Imazato S, Antonucci JM, Lin NJ, Lin- Gibson S, et al.. Effects of dual antibacterial agents MDPB and nano-silver in primer on microcosm biofilm, cytotoxicity and dentine bond properties. J Dent 2013;41:464-474.

23. Bradshaw DJ, Marsh PD, Hodgson RJ, Visser JM. Effects of glucose and fluoride on competition and metabolism within in vitro dental bacterial communities and biofilms. Caries Res 2002;36:81-86.

24. Li YH, Hanna MN, Svensäter G, Ellen RP, Cvitkovitch DG. Cell density modulates acid adaptation in Streptococcus mutans: implications for survival in biofilms. Bacteriol 2001;183:68756884.

25. Paes Leme AF, Koo H, Bellato CM, Bedi G, Cury JA. The role of sucrose in cariogenic dental biofilm formation - new insight. J Dent Res 2006;85:878-887.

Received November 21, 2016 Accepted May 31, 2017 